\title{
平板に衝突する超音速噴流中に形成される衝撃波の挙動
}

\author{
鈴木 宏昌 ${ }^{* 1}$, 遠藤 正樹 ${ }^{* 2}$, 榊原 洋子 ${ }^{* 2}$
}

\section{Behavior of shock waves formed in supersonic jet impinging on flat plate}

\author{
Hiromasa SUZUKI*1 ${ }^{* 1}$ Masaki ENDO*2 and Yoko SAKAKIBARA*2 \\ ${ }^{* 1}$ Graduate School of Advanced Science and Technology, Tokyo Denki University \\ Ishizaka, Hatoyama-machi, Hiki-gun, Saitama 350-0394, Japan \\ ${ }^{* 2}$ Division of Electronic and Mechanical Engineering, Tokyo Denki University \\ Ishizaka, Hatoyama-machi, Hiki-gun, Saitama 350-0394, Japan
}

\section{Received 14 March 2014}

\begin{abstract}
This paper focuses on the behavior of shock waves formed in an underexpanded impinging jet. The jet becomes underexpanded when the pressure ratio exceeds the critical value across the convergent nozzle discharging it. When a flat plate is placed perpendicularly to the jet, the strong shock wave called 'plate shock' appears in the flow field near the plate. The underexpanded jet discharged from a nozzle into the atmosphere is often used for industrial applications, e.g., an assist gas of laser cutting and a cooling jet in glass tempering process. The jet impinges on the work piece and spreads out on its surface. So this study concentrates on the relation between the jet oscillation and the location of the work piece and especially discusses behavior of shock formed in jet. The impinging jet was formed under conditions of different nozzle pressure ratios and nozzle-plate spacings and was visualized using the shadowgraph and schlieren methods. The instantaneous shape of jet was measured through analyzing the pictures taken at random under each condition and the oscillation pattern was examined. In addition, under the same conditions, a numerical study was carried out using TVD scheme. As a result, it was found that the oscillation pattern of plate shock depends on its location and the nozzle pressure ratio.
\end{abstract}

Key words : Underexpanded jet, Plate shock, Visualization, Oscillation, TVD scheme

\section{1. 序論}

超音速噴流の一つである不足膨張噴流は, 先細ノズルから大気中にノズル前後の圧力比を臨界圧力比以上で噴 出させた時に生じ, 樽型の連なるセル構造をもつ．この噴流はノズル出口面において流速がほぼ音速となり，光 の下流では超音速となる．噴流内では膨張波，圧縮波および衝撃波の影響により非一樣な流れとなる．また，ノ ズル前後の圧力比が大きくなる (不足膨張度が高くなる) と噴流内にマッハディスクが形成される．不足膨張噴流 の下流に流れに対して垂直に平板を置くと，噴流は平板に衝突し，光の前方にプレート衝撃波と呼ばれる衝撃波 が生じる .このプレート衝撃波と平板の間には, ノズル平板間距離やノズル前後の圧力比によって, 逆流あるい は渦が生じる.また，プレート衝撃波を通過した流体は平板に沿って放射状に流れ，壁面噴流を形成する.壁面 噴流においても，膨張波や圧縮波か噴流境界と平板との間で反射を繰り返すことで衝撃波が生じる．

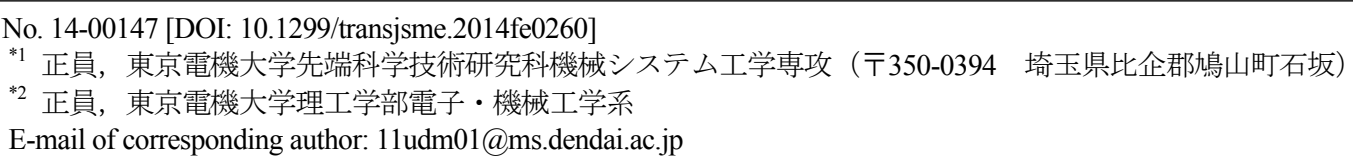


自由噴流では航空機やロケット等の排気噴流として, 衝突噴流では, 自動車や航空機等に用いられている熱強化 ガラス製作時の冷却噴流 (Aratani and Ojima, 1991) , (Barsom, 1698)，板金部品などの薄肉状の精密加工を要する際 に用いられるレーザ加工における補助噴流 (Fieret, et al., 1987) などとして，工業的な分野で広く利用されている . 熱強化ガラスの製造工程で用いられている冷却噴流では, ガラス・噴流間での熱流束が冷却性能を左右する . この 熱流束は噴流の挙動およびガラス近傍に生じるプレート衝撃波の挙動との関連が深いと考えられている (玉井他， 2002）．レーザ加工においては，レーザ切断時に生じる溶融物の除去に用いられている．したがって，物体上のよ どみ点圧力は除去効率の重要な因子であり，熱流束と同樣に噴流および衝撃波の挙動の影響を受ける．さらに，こ の流れ場では，噴流境界近傍に渦が生じており，この渦と噴流は干渉する．弚の際に高周波のスクリーチ音と呼 ばれる騒音 (Powell, et al., 1992) も発生する .こうした背景から噴流の挙動を把握することは工学上極めて重要で あり，これまでにも多岐にわたり研究がなされてきた．光の多くは主噴流の流れ場を対象としている．自由噴流 では, 流れ場に生じる音波の周波数や音圧解析 (Powell, et al., 1992), (Powell, 1988), スクリーチ現象のフィード バック機構 (Tam, 1992), (Raman, 1997)，(Panda, 1998) に関する研究が行われている.一方, 衝突噴流では, 数値 解析によるプレート衝撃波の形成機構の検討 (Iwamoto and Deckker, 1981), 平板上の圧力変動と流れ場に生じる音 波の周波数解析 (田村, 岩本, 1994), 平板近傍に生じる逆流現象 (岩本, 井野川，1989) である录離泡の発生の検 討 (楿原, 岩本, 1994)などの研究が行われている.さらに, 壁面噴流のみを対象とした放射状噴流の研究も行わ れている (遠藤他，2006)，(榊原他，2005).しかしながら，この物体に衝突する不足膨張噴流の挙動は高速でかつ 非定常な性質を有することから，噴流や衝撃波の挙動の定量的な解析はあまりなされていない．

そこで, 本研究では不足膨張衝突噴流の主噴流の挙動について, 光学的手法を用いて流れ場の可視化を行った . その可視化結果より，不足膨張度の低い状態とマッハディスクが形成されるような高い状態のセル構造および衝撃 波に着目し, 非定常な变動を統計的に解析することて噴流の挙動の解明を試みた .さらに, 可視化実験と同樣の 条件で実施した数值解析の結果からも噴流構造の解明を試みた 。

記号

$\begin{array}{ll}D & : \text { ノズル直径 } \\ l & : \text { ノズル平板間距離 } \\ l_{n} & : \text { セル節位置 } \\ \overline{l_{n}} & : \text { セル節位置の平均 } \\ l_{a s} & : \text { 環状衝撃波位置 } \\ \overline{l_{a s}} & : \text { 環状衝撃波位置の平均 } \\ l_{b p} & : \text { プレート衝撃波底辺位置 } \\ \overline{l_{b p}} & : \text { プレート衝撃波底辺位置の平均 } \\ l_{v p} & : \text { プレート衝撃波頂点位置 } \\ \overline{l_{v p}} & : \text { プレート衝撃波頂点位置の平均 } \\ n & : \text { 各条件におけ枯る可視化サンプル数 }\end{array}$

$\begin{array}{ll}p & : \text { 圧力 } \\ p_{a} & : \text { 大気圧 } \\ p_{0} & : \text { タンク内よどみ点圧力 } \\ R & : \text { ノズル曲率半径 } \\ x & : \text { 数值解析での噴流軸方向座標 } \\ y & : \text { 数値解析での噴流半径方向座標 } \\ \alpha_{n} & : \text { セル節の傾き } \\ \alpha_{p} & : \text { プレート衝撃波底辺の傾き } \\ \rho & : \text { 密度 } \\ \rho_{0} & : \text { タンク内密度 } \\ \sigma & : \text { 標準偏差 }\end{array}$

\section{2. 実験装置および方法}

\section{$2 \cdot 1$ 配管系}

配管系の概略を図 1 に示す . 本実験で扱っている高圧空気はコンプレッサによって圧縮後 , エアドライヤにより 冷却除湿され，脈動成分を除去するためにサージタンクに送られる．弚の後，オイルミストセパレータにより油 分を除去された後, 先細ノズルが取り付けられた高圧タンク内に供給され，大気へ噴出される．ノズル中心軸上 に垂直に設置した平板に不足膨張噴流を衝突させることで, 本研究の対象である衝突噴流の流れ場を形成させた . また，圧縮空気の湿度か衝撃波の発生位置や形状に影響を及ぼすことから (Otobe, et al., 2011)，高圧タンク内に乾 燥剂 (シリカゲル) を入れ除湿している . また流れを一樣にするために整流格子もタンク内に設置している.配管 
を通過し供給される空気は, 高圧タンク内においてよどみ点状態に回復したところで先細ノズルから噴出される . 大気圧は実験室内に設置されたフォルタン型水銀差圧計を用いて計測している . タンク内のよどみ点圧力はデジ タルマノメータによって計測しており，バイパス側に設置されたバルブによりタンク内の圧力を調整している．先 細ノズルの周りには上流へ伝播する音波の反射の影響を抑えるために吸音材を取り付けている .

\section{$2 \cdot 2$ 実験方法}

本研究ではノズル出口直径 $D=10 \mathrm{~mm}$, ノズル曲率半径 $R=20 \mathrm{~mm}$ の円形先細ノズルを使用し，ノズル中心軸 上に平板を設置し，不足膨張衝突噴流を形成させた . 大気圧に対するタンク内圧力の比 $p_{0} / p_{a}$ を $3.0,3.4,3.8$ の 3 種類用い, 各圧力比におけるノズル平板間距離を $l / D=1.5$ から 2.5 まで変化させた際の流れ場を調べた .

可視化にはシュリーレン法およびシャドウグラフ法を採用した . 光源には閃光時間 $180 \mathrm{~ns}$ のナノパルスライト を用いており，カメラのシャッターを開放状態で光源をスパークさせることにより撮影を行った .したがって，写 真の露光時間は光源の閃光時間となる .

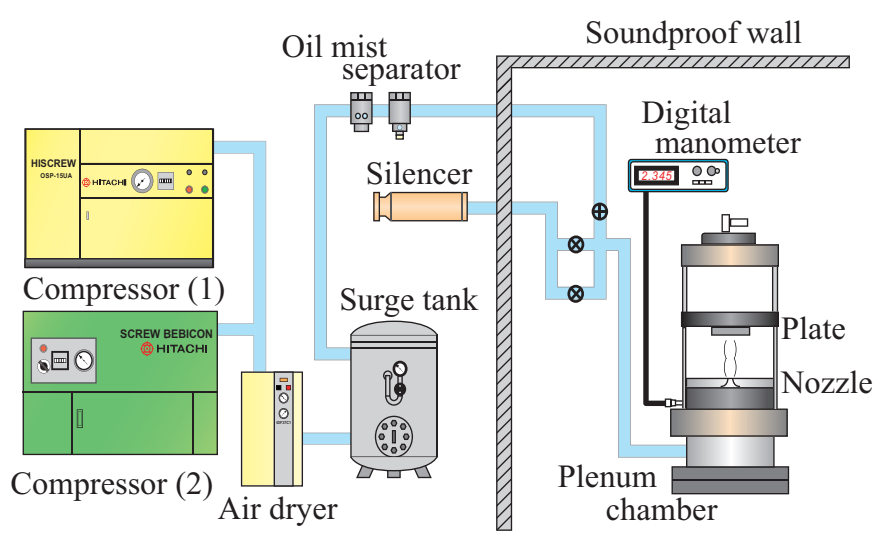

Fig. 1 Piping system. The air is compressed by screw compressors and passes through the air dryer, surge tank, and oil mist separator. The compressed air is supplied into a plenum chamber to which a convergent nozzle is attached.

\section{3. 数 值 解 析 手法}

本研究では, 光学的可視化では解析が困難な詳細な噴流構造の解明のため, 実験と同樣の 3 種類の圧力比におい て不足澎張衝突噴流の数值解析を行った . 解析にはオイラー方程式を支配方程式とし，2 次精度風上型 TVD 差分 法(Yee, 1987) を採用した . また，制限関数として $\operatorname{minmod}$ を用い，時間積分は前進差分に時間 2 次精度の項を加 えて行った . 本研究での数值解析では, 流れ場は軸対称と仮定し, 平板には弾性変形が無いものとしている. 計 算領域には噴流軸方向を $x$ 軸，噴流半径方向を $y$ 軸とした直交座標系に計算格子が与えられている $y$ 軸では, 計 算領域はノズル直径 $D$ の 7.5 倍とし, 兴の領域に 150 格子が設けられている. 格子間隔は噴流中心軸に向かって 密となっている . 中心軸から離れるほど格子間隔を大きくしていくことにより，格子粘性の効果を用いて $y=7.5 D$ の境界でのじょう乱を抑えている.$x$ 軸では, 格子数はノズル平板間距離により決定され，格子間隔は $0.04 D$ の等 間隔に設けられている．本解析において，格子間隔を変更した際に光の影響を受けるのは主に前述の壁面噴流部 分のみであり，噴流構造および衝突領域への影響はほとんどないことは確認されている . 高圧タンク内のよどみ 点状態の諸量から得られる臨界状態がノズル出口面て設定されている．噴流軸は反射境界とし，ノズル周りのバッ フルプレートと平板はすべり壁としている.他の境界条件については, リーマン变数は一定として与えられてい る.なお, 本研究の解析手法は妥当であり，噴流中の圧縮領域や膨張領域の形状，プレート衝撃波の形成位置，は く離泡の形成などに関し，実験結果との良い一致が確認されている (Sakakibara and Iwamoto, 2002) . 


\section{4. 結果および考察}

$4 \cdot 1$ 衝突噴流の可視化解析

図 2 , 図 3 および図 4 に異なる圧力比 $p_{0} / p_{a}=3.0,3.4,3.8$ におけるノズル平板間距離 $l / D=1.5$ から 2.5 まで変 化させた流れ場のシャドウグラフ法による可視化写真を示す . 各写真の下端がノズル出口 , 上端が平板であり , 噴 流は下から上に向かって噴出している .これらの可視化結果から，プレート衝撃波の形成位置が第 1 セル内から第 2 セル内へと変化していく過程を調べた . 各図とも $l / D$ の増加に伴い, プレート衝撃波の形状は変化し, 形成位置 が下流へと移動していくことがわかる . なお，可視化写真での解析のため，流れ場および衝撃波の形状を 2 次元 形状で表現している.例えば, 図 2 において，l/D=1.5 から $1.7 て ゙$ 第 1 セル内に形成されているプレート衝撃波 は $l / D=1.8$ では第 2 セルに移動している . また, これらの図よりプレート衝撃波の形状は, 弓形, 台形および平 形の 3 種類に大別される.

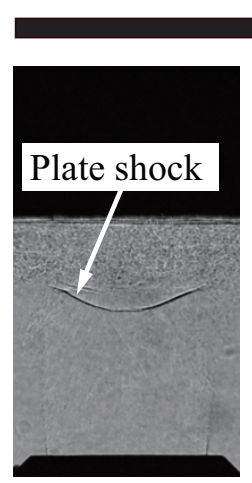

(a) $l / D=1.5$

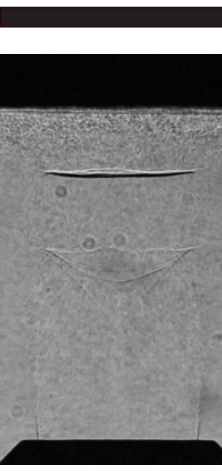

(g) $l / D=2.1$

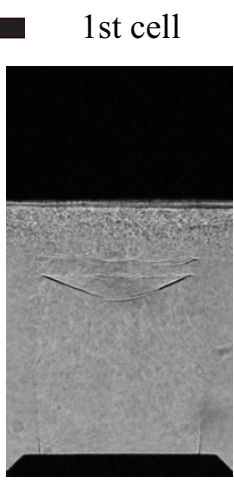

(b) $l / D=1.6$

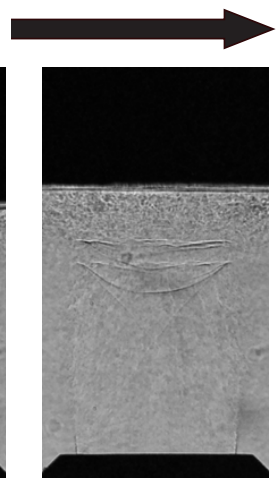

(c) $l / D=1.7$

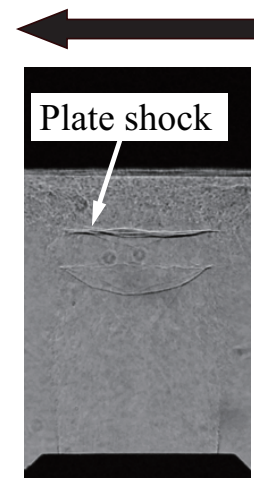

(d) $l / D=1.8$

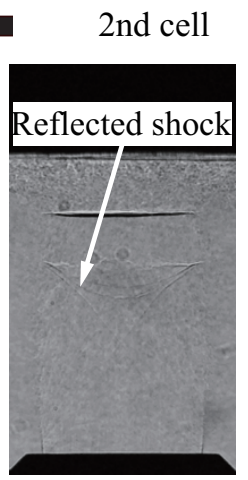

(e) $l / D=1.9$

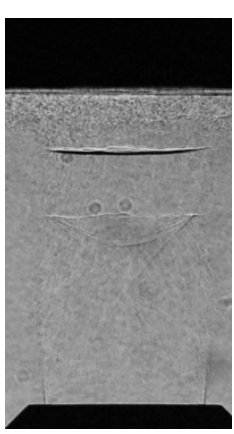

(f) $l / D=2.0$

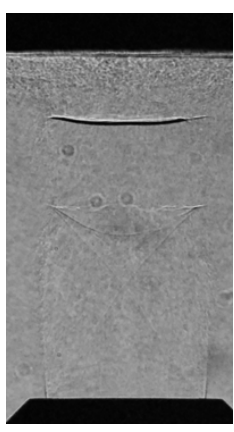

(h) $l / D=2.2$

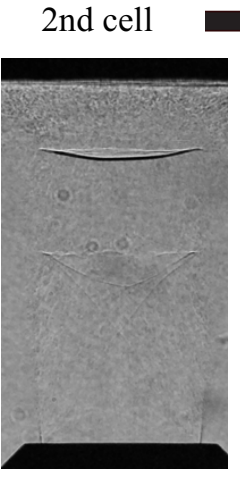

(i) $l / D=2.3$

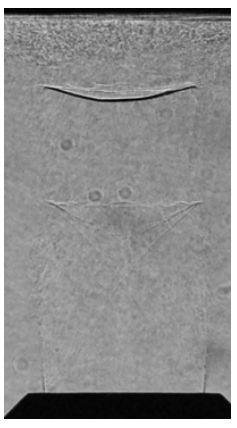

(j) $l / D=2.4$

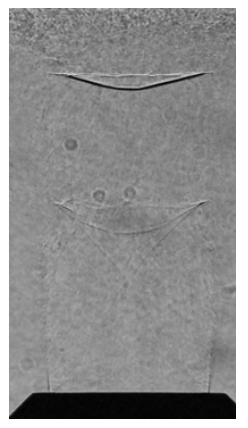

(k) $l / D=2.5$

Fig. 2 Visualization photograph by the shadowgraph method at $p_{0} / p_{a}=3.0$. Changes of shape and position of plate shock with increase in $l / D$.

各図においてプレート衝撃波の形状と位置の推移を比較すると，図 3 は台形 $(l / D=1.5,1.6)$ から, 台形の上底部 が湾曲し $(l / D=1.7,1.8)$, 第 2 セルへ移動後に平形 $(l / D=1.9 \sim 2.4)$ となる .さらに $l / D$ か増加するとプレート衝 撃波は弓形 $(l / D=2.5)$ となる．すなわち，プレート衝撃波の形状の推移から，台形には上底部が「湾曲する場合」 と「湾曲しない場合」の 2 種類が存在することがわかる .このプレート衝撃波の形状変化の過程は図 2 の $p_{0} / p_{a}=$ 3.0 においても同樣の傾向を示している.

図 4 は, プレート衝撃波は第 1 セル内で常に台形となり，図 2 および図 3 とは形状変化の過程が異なる．これ は不足膨張度が高くなったことで, プレート衝撃波が常に入射衝撃波と干渉状態にあるためである．プレート衝 
撃波の第 2 セル移動後の $l / D=2.3$ において, 第 1 セルにマッハディスクの形成が確認できることからも不足膨張 度が図 2 および図 3 よりも高いことがわかる. 第 2 セル移動後のプレート衝撃波の形状は平形となり，図 2 およ び図 3 と同樣の傾向を示す.

さらに，プレート衝撃波の下流の領域ではいくつかの可視化結果に弱い衝撃波が生じていることか確認できる． 図 3 の $l / D=1.5$ および 1.6 , 図 4 の $l / D \leq 2.2$ でプレート衝撃波の下流に弱い衝撃波が生じている . 図 5 は $p_{0} / p_{a}=$ 3.4 における $/ / D=1.5$ と 1.7 での流れ場の特徴を模式化したものである.弱い衝撃波が形成される場合は，図 5(a) より，プレート衝撃波と入射衝撃波が干渉していることがわかる．一方，弱い衝撃波が形成されない場合は，図 5(b)のようにプレート衝撃波は反射衝撃波との干渉状態にある．このことから，弱い衝撃波の形成にはプレート 衝撃波の干渉状態が影響していると考えられる.なお， $p_{0} / p_{a}=3.0$ では, $l / D=1.2$ から 1.3 付近で同樣の現象が確 認されている。
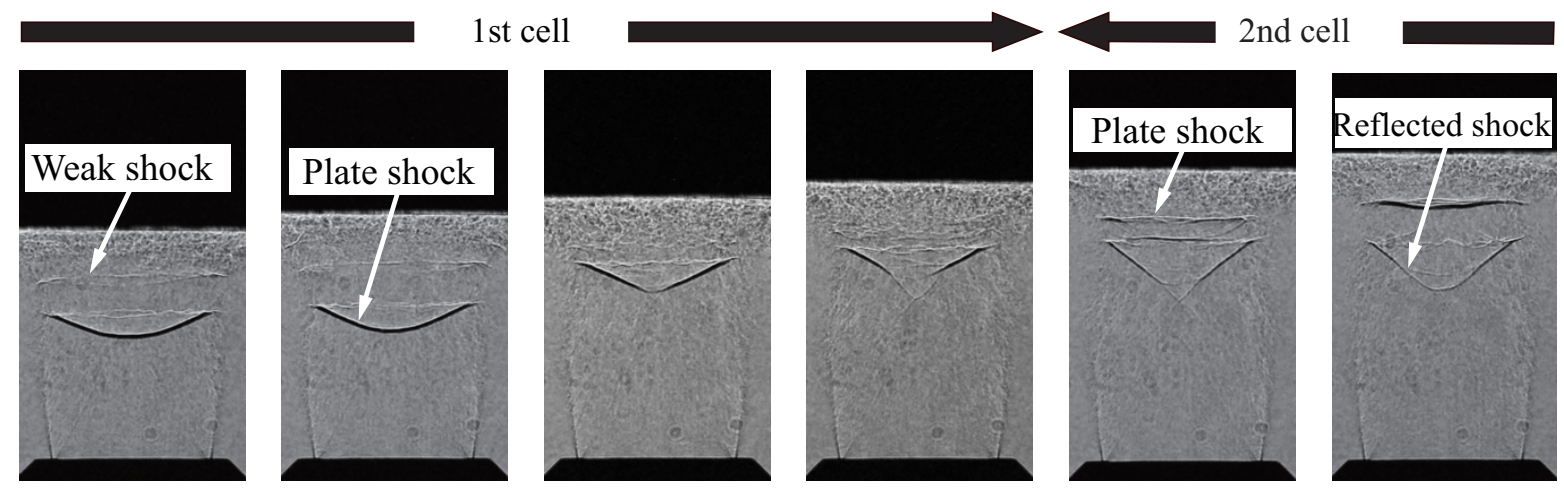

(a) $l / D=1.5$

(b) $l / D=1.6$

(c) $l / D=1.7$

(d) $l / D=1.8$

(e) $l / D=1.9$

(f) $l / D=2.0$
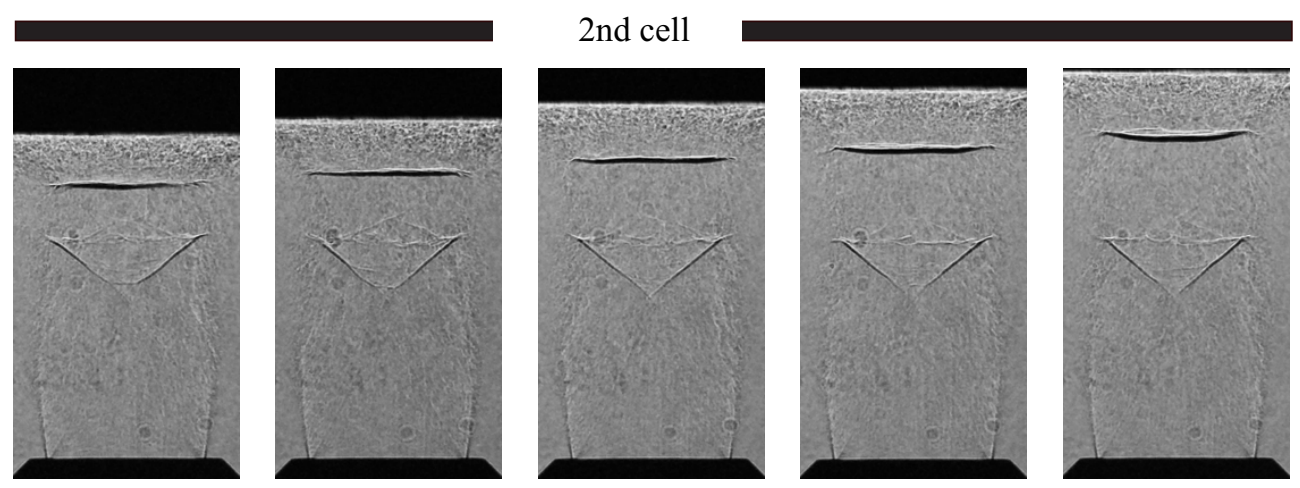

(g) $l / D=2.1$

(h) $l / D=2.2$

(i) $l / D=2.3$

(j) $l / D=2.4$

(k) $l / D=2.5$

Fig. 3 Visualization photograph by the shadowgraph method at $p_{0} / p_{a}=3.4$. Changes of shape and position of plate shock with increase in $l / D$. 


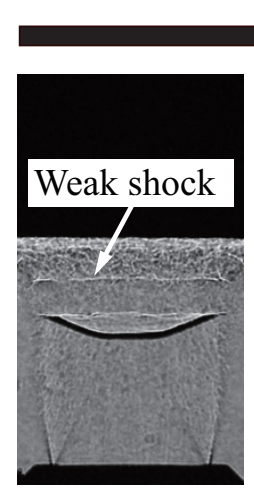

(a) $l / D=1.5$

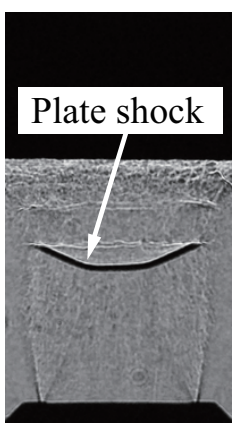

(b) $l / D=1.6$

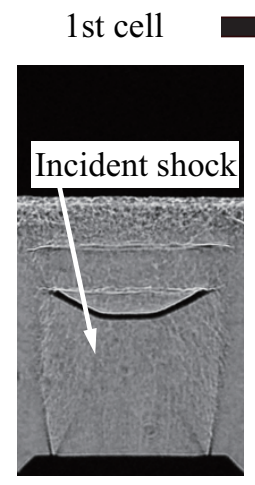

(c) $l / D=1.7$

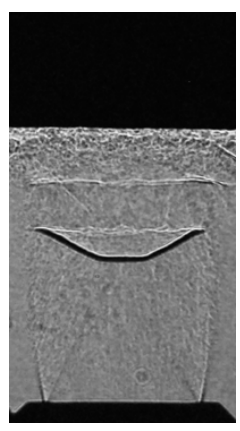

(d) $l / D=1.8$

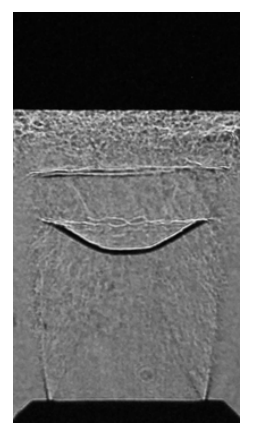

(e) $l / D=1.9$

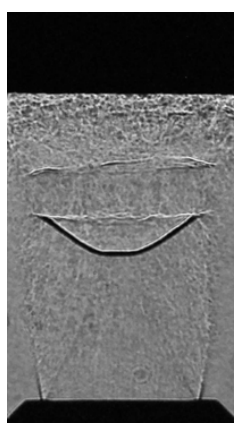

(f) $l / D=2.0$

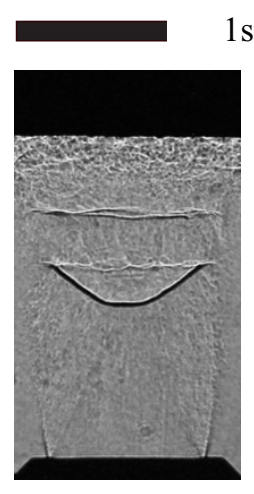

(g) $l / D=2.1$

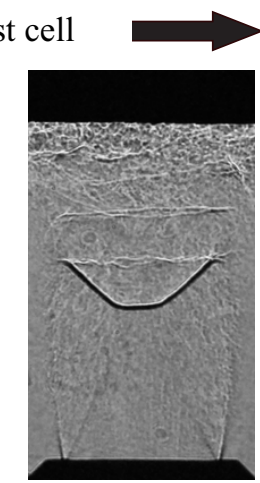

(h) $l / D=2.2$

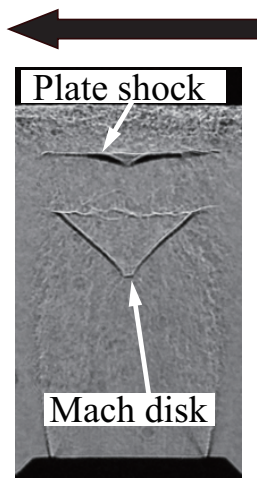

(i) $l / D=2.3$

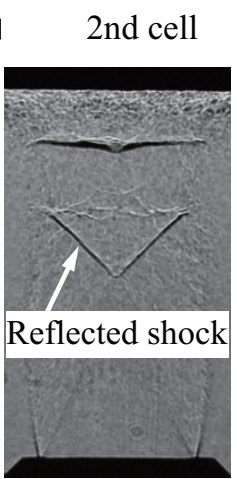

(j) $l / D=2.4$

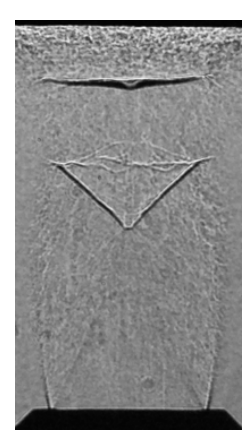

(k) $l / D=2.5$

Fig. 4 Visualization photograph by the shadowgraph method at $p_{0} / p_{a}=3.8$. Changes of shape and position of plate shock with increase in $l / D$.

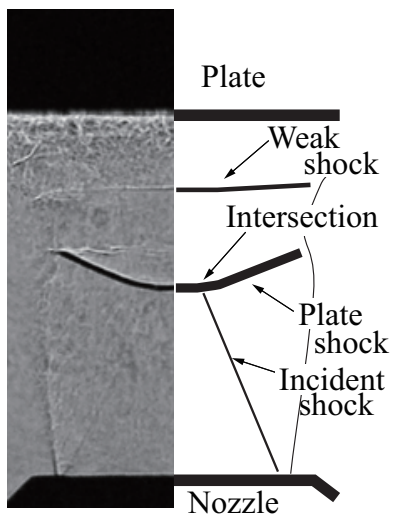

(a) $l / D=1.5$, with weak shock

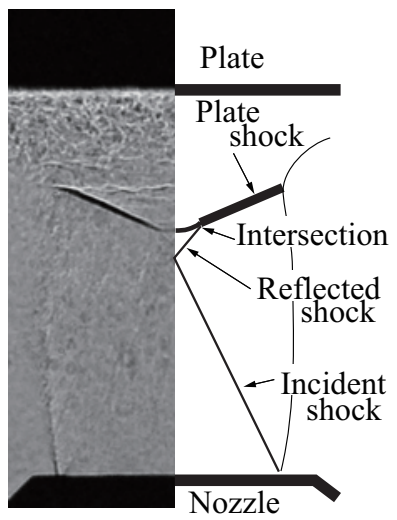

(b) $l / D=1.7$, without weak shock

Fig. 5 Illustration of flow field at $p_{0} / p_{a}=3.4$. (a) indicates interaction between plate shock and incident shock. (b) indicates interaction between plate shock and reflected shock.

図 6 に $p_{0} / p_{a}=3.4$ での数值解析の結果を示す.解析結果の各図の左側半分は等密度線図を示し，右側は等圧力 線図を示している. 図 3 で弱い衝撃波が確認された $l / D=1.5$ の結果である図 6(a) では，プレート衝撃波と入射衝 撃波が干渉していることがわかる．さらに，乥れらの干渉点から接触面が形成されていることが確認できる. 一 方, 弱い衝撃波が形成されない図 6(b) では, 可視化結果と同樣にプレート衝撃波と反射衝撃波が干渉しており，こ 
の状態においては接触面も形成されていないことがわかる .このことから，弱い衝撃波はプレート衝撃波端から 生じた膨張波が接触面と噴流境界の間で反射し，圧縮波が重なることで衝撃波へと遷移すると考えられる．した がって，この弱い衝撃波は噴流境界と接触面に挟まれた領域にのみ形成されるため，3 次元的に捉えると衝撃波の 形状は環状となる。

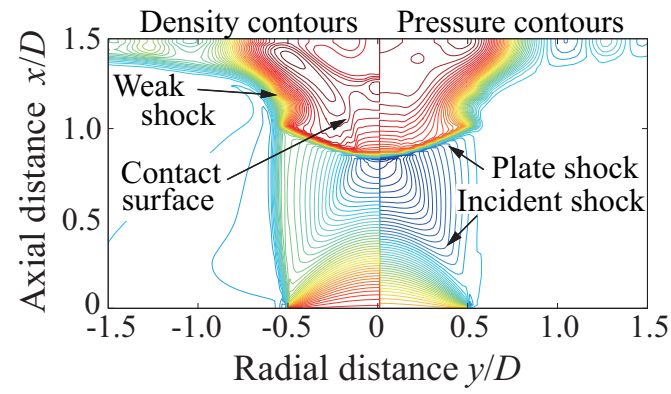

(a) $l / D=1.5$

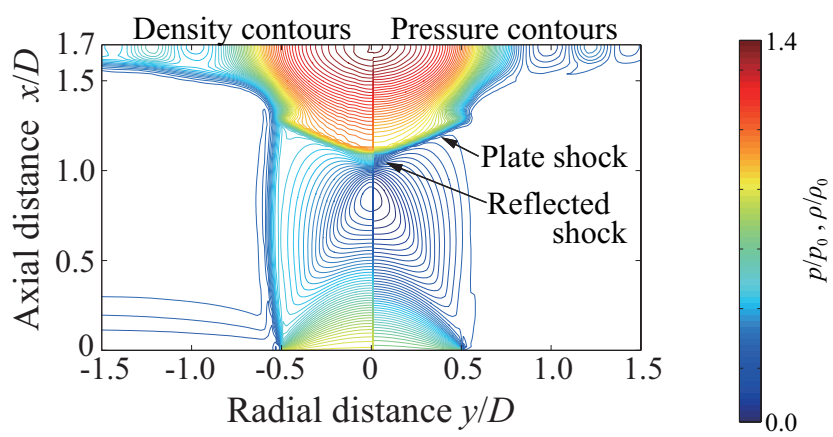

(b) $l / D=1.7$

Fig. 6 Density contours and pressure contours at $p_{0} / p_{a}=3.4$. (a) indicates interaction between plate shock and incident shock. The contact surface originating at the intersection of plate shock and incident shock. (b) indicates interaction between plate shock and reflected shock.

\section{$4 \cdot 2$ 流れ場の時間平均的特性}

本研究では 3 種類の圧力比を用いて , ノズル平板距離を変化させた際の流れ場を調べた . 各条件で 50 枚の写真 を用いて, 図 7 に示されるセル節の位置 $l_{n}$, プレート衝撃波の頂点と底辺の位置 $l_{v p}, l_{b p}$, 環状衝撃波の位置 $l_{a s}$, セル節とプレート衝撃波の傾き $\alpha_{n}, \alpha_{p}$ を計測した .

図 8 に可視化写真から得られた各圧力比における衝撃波およびセル節の平均位置を示す. 図中の白色プロット はプレート衝撃波，黑色は第 1 セルの節を示しており，実線は平板の位置，破線は自由噴流状態でのセル節の位 置を示している．セル節のプロットが示された範囲からプレート衝撃波は第 2 セルへ移動したことを示している また， 50 枚のデータから算出された平均値の誤差率は $0.1 \%$ 程度であり，特性の考察には影響がないことを確認し ている.さらに，200 枚のサンプル数を用いて 1 枚から 200 枚まで 1 枚ずつサンプル数を増加させた場合の平均 值の推移を解析し，サンプル数が 30 枚から 40 枚程度で值が一定の值へと収束することを確した .よって，本論 文ではサンプル数を 50 枚としている.

全ての圧力比に共通していることは, プレート衝撃波の頂点と底辺の位置は $l / D$ の増加に伴い下流方向へ移動し ていく点である . 同時にプレート衝撃波の頂点と底辺間の距離も増加していく．このことから，プレート衝撃波 の頂点よりも底辺の方が $l / D$ の増加に伴う移動量は大きいことがわかる . このプレート衝撃波の頂点と底辺間の距 離はプレート衝撃波が第 1 セルの領域内に存在する間は増加し, プレート衝撃波が第 2 セルへ移ると急激に減少 する . 形状が平形の間は変化せず，弓形になるとプレート衝撃波の下流への移動に伴い徐々に増加していく . しか しながら，l/Dの増加に伴うプレート衝撃波の下流領域への移動の過程は, 図 8(a), (b) と図 8(c) では異なること がわかる. 図 8(a) および (b) では, プレート衝撃波の底辺位置が自由噴流状態での第 1 セル端付近に到達後，第 2 セルへ大きく移動する . また, 図 8(b) では, 環状衝撃波の消失後にプレート衝撃波は下流へ大きく移動している ことがわかる $(l / D=1.6 \sim 1.7)$. 一方の図 8(c) では, プレート衝撃波の底辺位置が自由噴流状態での第 1 セル端付 近に到達せずに $l / D=2.2$ から 2.3 の間で第 2 セルへと移動し, 光の移動量も図 8(a), (b) に比べ非常に大きい . 光 の要因は，不足膨張度の高さであり，流れ場の状態が異なることが影響していると考えられる . 図 4 でも確認で きるようにプレート衝撃波が第 1 セル内に存在する間は入射衝撃波との干渉状態にあることで, 常に環状衝撃波 も存在している .このため, プレート衝撃波の下流への移動量が他の圧力比と比較して増大したと考えられる . 


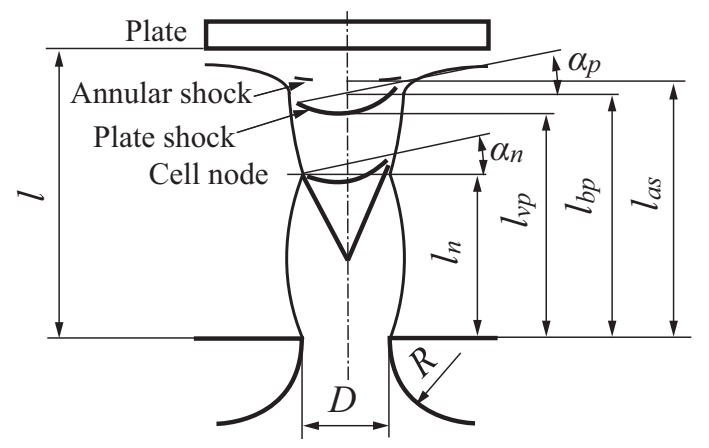

Fig. 7 Measurement points. The location of cell node $l_{n}$, the locations of plate shock $l_{b p}, l_{v p}$, the location of annular shock $l_{a s}$ and the inclinations of cell node and plate shock $\alpha_{n}, \alpha_{p}$ are measured.

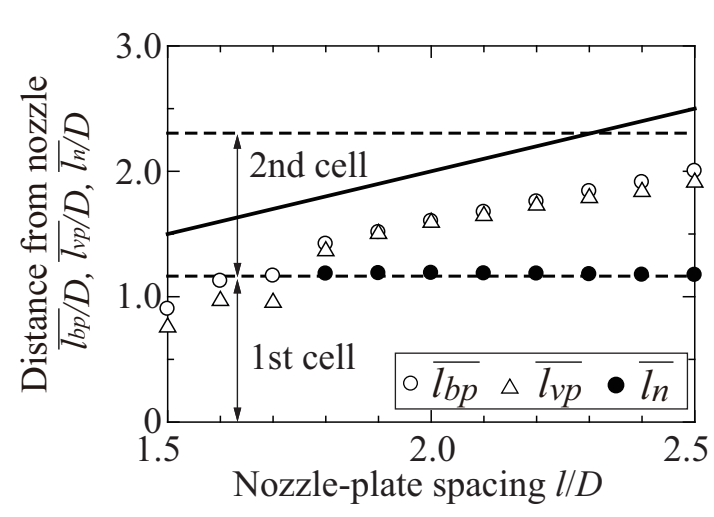

(a) $p_{0} / p_{a}=3.0$

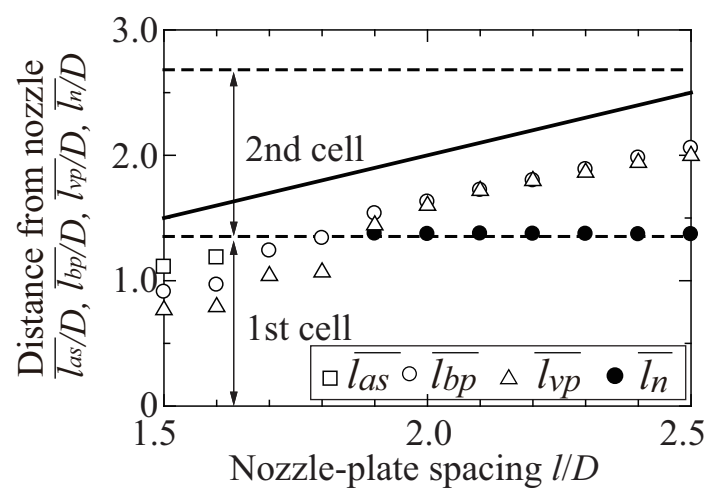

(b) $p_{0} / p_{a}=3.4$

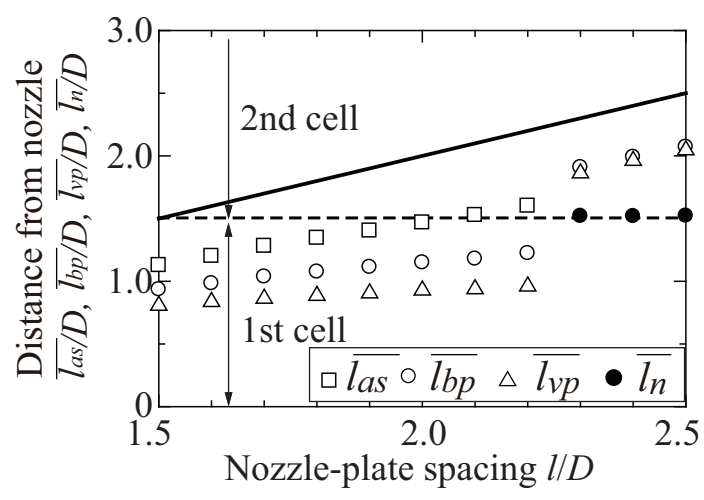

(c) $p_{0} / p_{a}=3.8$

Fig. 8 Average location of cell node and shocks. These distances are nondimensionalized by the diameter of nozzle exit $D$. The empty markers denote the locations of shocks and the solid one the cell node. The solid line is the location of plate. The dashed lines are the cell nodes of free jet. The location of plate shock moves downstream with increase in $l / D$, and it jumps from 1 st cell to 2 nd cell.

\section{$4 \cdot 3$ 噴流の挙動解析}

図 9 に $p_{0} / p_{a}=3.4, l / D=1.8$ におけるシュリーレン法による可視化写真を示す . 図 9 の (a) から (e)の各写真に は時間的連続性は無く，無作為に抽出された瞬間の流れ場を示している．ナイフエッジは噴流軸に垂直に設置し， 上流側から遮光するように設定している．したがって，写真上では圧縮領域は白色に，膨張領域は黑色となる．図 
9 の各写真の噴流構造を比較すると，膨張領域，圧縮領域やプレート衝撃波の形状や位置が写真毎に異なり，流れ 場の時間的な変動が確認できる. 図 10 は図 9 と同条件である 50 枚の可視化結果より計測したプレート衝撃波の 頂点と底辺の位置, ノズル出口面に対するプレート衝撃波の傾き角を示している.プレート衝撃波は底辺位置に 比へ頂点位置の変動が大きく，ノズル出口面に対する傾き角は $\pm 2^{\circ}$ の範囲内で変動していることがわかる .すな わち, この場合のプレート衝撃波の挙動は, 噴流軸方向の底辺位置の変動は小さく，頂点部分の変動が大きくな り, 左右に傾く特徵をもっていると判断できる. 弚こで, 本研究では 3 種類の異なる圧力比におけるノズル平板 間距離を変化させた際の流れ場の挙動について, 噴流軸方向の変動および非軸対称な変動に焦点をあて調べた .

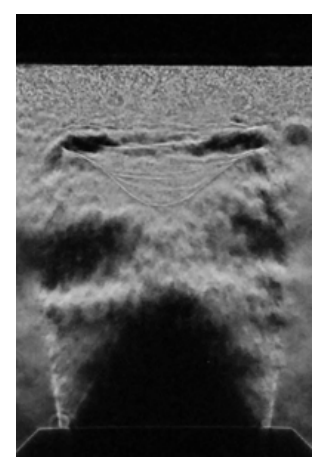

(a)

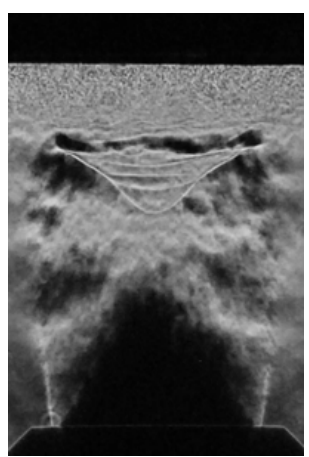

(b)

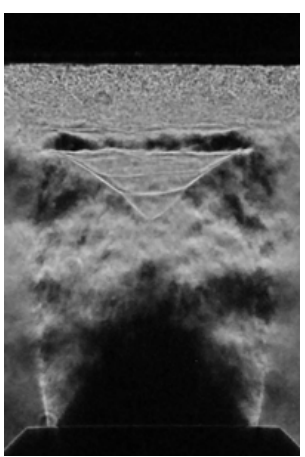

(c)

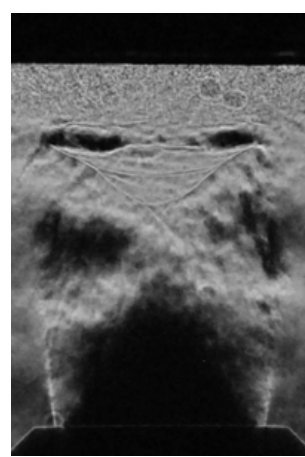

(d)

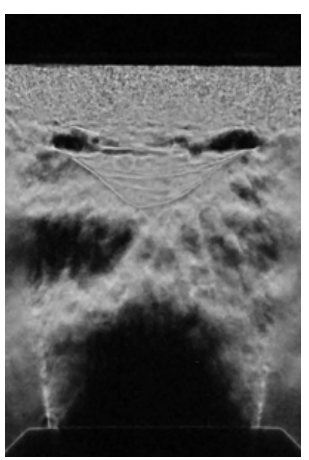

(e)

Fig. 9 Schlieren photographs at $p_{0} / p_{a}=3.4, l / D=1.8$. The nozzle exit is in the lower side of each picture. The knife edge is placed in the direction normal to jet axis so that the expansive region is dark and compressive region bright. These are instantaneous flow fields taken at random. Comparing the flow fields with each other, the expansive region, the compressive region and plate shock is seen to be deformed.

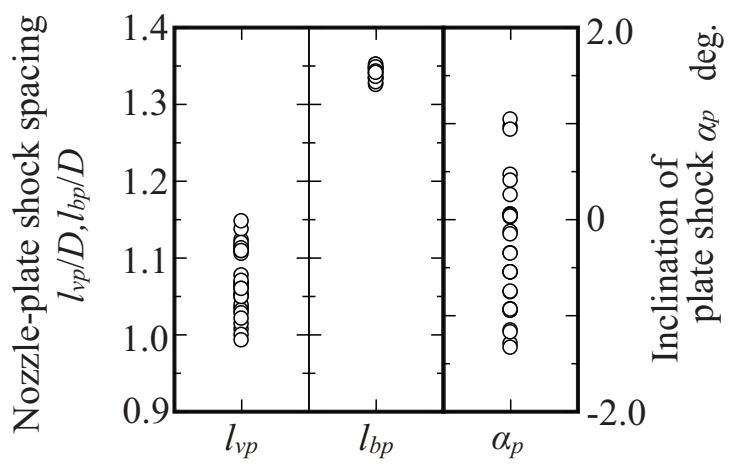

Fig. 10 Behavior of plate shock at $p_{0} / p_{a}=3.4, l / D=1.8$. This shows the variations in measurement data of $l_{b p}, l_{v p}$ and $\alpha_{p}$. Plate shock moves along jet axis and inclines simultaneously.

\section{4·3·1 噴流軸方向の振動}

図 11 にプレート衝撃波およびセル節の位置の偏差を示す . 図中の破線はプレート衝撃波の形成領域の境界を示 しており，破線の左側が第 1 セル内，右側が第 2 セル内となる . 図中の下端部は可視化結果より観察された各 $l / D$ でのプレート衝撃波の形状を示している .この偏差はプレート衝撃波およびセル節位置の噴流軸方向の変動を表 している . 式 (1) にプレート衝撃波の頂点位置 $l_{v p}$ の偏差の算出式を示す . 本研究て議論する他の偏差についても 同樣の算出法を用いている . 


$$
\sigma=\sqrt{\frac{\sum_{k=1}^{n}\left(l_{v p_{k}}-\overline{l_{v p}}\right)^{2}}{n-1}}
$$

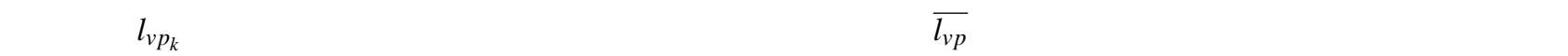
は $n=50$ である. 50 枚のデータから算出された偏差の誤差率は $5 \%$ に満たない值であり，前述した平均值と同樣 に特性の考察には影響がないことを確認している．また，サンプル数の妥当性については，平均值の場合と同樣 に 30 枚から 40 枚のサンプル数で值が収束することを確認している .

図 11 も図 8 と同樣に, 不足膨張度の低い $p_{0} / p_{a}=3.0,3.4$ である図 $11(\mathrm{a})$ および (b) と不足膨張度の高い $p_{0} / p_{a}=$ 3.8 の図 11(c) で異なる傾向を示した . まず, 図 11(a) および(b) では, 第 1 セル内でプレート衝撃波の頂点位置の 変動が底辺位置に比へ特に卓越している.卓越する $l / D$ は, 図 $11(\mathrm{a})$ では $l / D=1.7$, 図 11(b) では $l / D=1.8$ となり， これらの $l / D$ は図 8 で示されるようにプレート衝撃波の底辺位置が自由噴流状態での第 1 セル端に近づき，第 2 セルへ移動する直前の距離である . 第 2 セルへ移動する直前の流れ場は, 反射衝撃波の発達が進み，プレート衝 撃波との干渉点が噴流中心軸から離れ，干渉点間の距離が大きくなっていることが図 2 および図 3 からもわかる . プレート衝撃波と入射衝撃波が干渉している $/ / D$ の範囲 (橙色) では, 反射衝撃波と干渉している範囲 (青色) に比 べると変動は小さいが, プレート衝撃波の頂点位置と底辺位置の双方が同程度の值で変動している .さらに頂点 位置よりも底辺位置の変動がやや大きく, 反射衝撃波とプレート衝撃波が干渉している状態とは変動の値が逆転 していることがわかる .

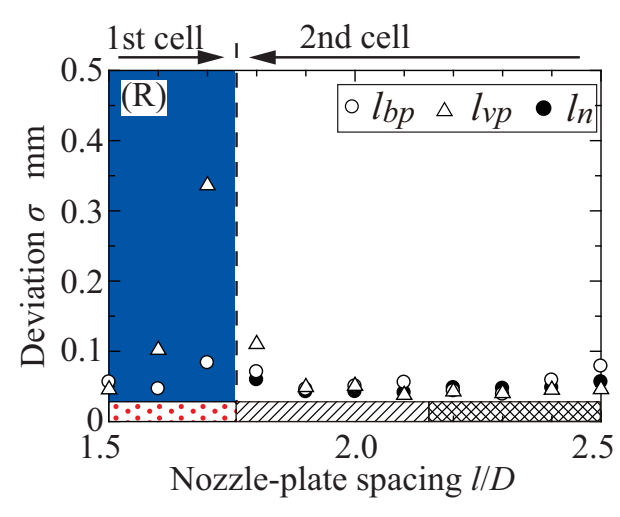

(a) $p_{0} / p_{a}=3.0$

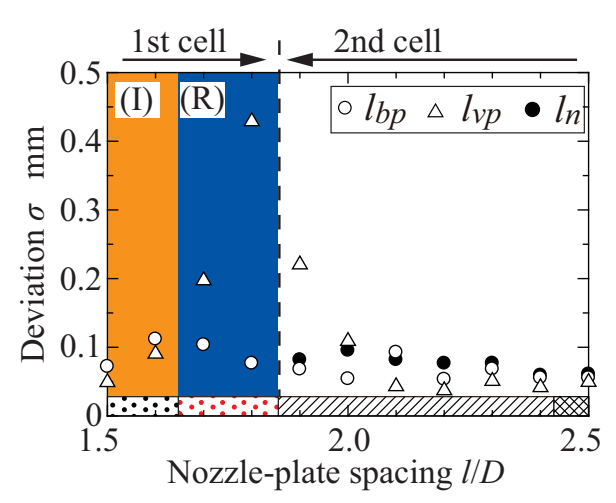

(b) $p_{0} / p_{a}=3.4$

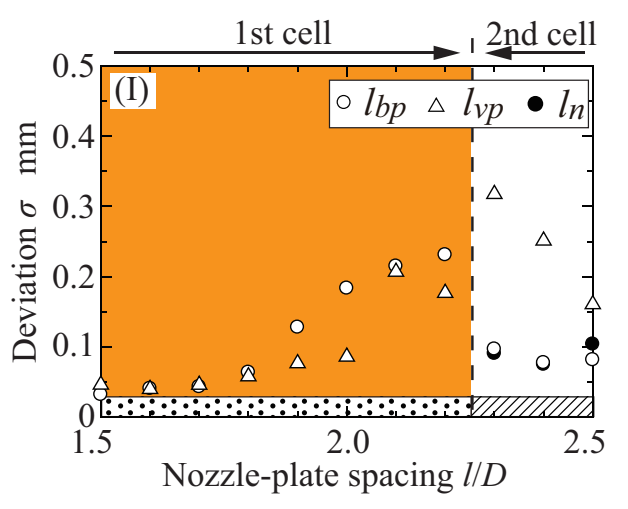

Shape of plate shock

VII Flat type

Bow type

$\therefore \because$ Trapezoid type

$\therefore$ Trapezoid type (with curvature)

(I) Interaction of plate shock and incident shock

(R) Interaction of plate shock and reflected shock

(c) $p_{0} / p_{a}=3.8$

Fig. 11 Deviations of plate shock location and cell node. Shape of plate shock is shown bottom of these figures. In (a) and (b), the deviation of $l_{v p}$ suddenly rise at $l / D=1.7$ and 1.8. In (c), $l_{v p}$ and $l_{b p}$ gradually increase from $l / D=1.8$. 
また , シャドウグラフ法による可視化写真での明暗は計測部での密度分布の 2 階微分すなわち空間的な密度変 化の勾配に比例する．したがって，同一条件下における写真上の衝撃波を捉えた明暗の模樣の幅から衝撃波強さ を相対的に比較することができる .ここで，図 2 から図 4 におけるプレート衝撃波の相対的な強さに注目すると， 図 $11(\mathrm{a})$ の $l / D=1.6$ や図 11 (b) の $l / D=1.8$ では反射衝撃波とプレート衝撃波の干渉点間の内側と外側ではプレー 卜衝撃波の強さが異なり，干渉点間の内側ではプレート衝撃波か溺くなっている．また，反射衝撃波とプレート衝 撃波に囲まれる領域においては, 反射衝撃波通過による圧力変動と流速の減少, 弚の後プレート衝撃波を通過す ることで圧力変動および带音速への減速が生じる複雑な流れとなっている．このため，プレート衝撃波の弱まる 干渉点より内側の領域にあたる頂点部分は，变動か増大すると考えられる．

一方, 図 11(c)では, 図 4でも示されるようにプレート衝撃波が第 2 セルへ移動するまでは常にプレート衝撃波 は入射衝撃波と干渉しており, プレート衝撃波の頂点位置に加え, 底辺位置の変動も大きくなっている.ここで も, 図 11(b) の場合と同樣にプレート衝撃波の底辺位置の変動か仃頁点位置の変動よりも大きくなっていることがわ かる.プレート衝撃波の頂点位置, 底辺位置ともにプレート衝撃波が第 2 セルに移動するまで变動は増加する傾 向を示す. 第 2 セル移動後は, プレート衝撃波の底辺は変動が減少するのに対し, 頂点部では再び卓越し変動が 大きくなる . これは第 2 セル移動後のプレート衝撃波が他の圧力比とは異なり，滑らかな平形 (図 2 の $l / D=1.9$ ， 2.0 , 図 3 の $l / D=2.0,2.1$ ) ではなく, 噴流軸付近に上流に向かう微小な突起のある平形 (図 4 の $l / D=2.3$ ) となる ためと考えられる .この突起部が大きく変動したため, 第 2 セル移動後もプレート衝撃波の頂点部の変動が大き くなる傾向を示したと考えられる .さらに, この突起部の半径方向の大きさは第 1 セル内のマッハディスクの大 きさとほぼ同程度であることが確認できる．第 1 セル内にマッハディスクが形成されると，マッハディスクを通 過する噴流軸付近の流れと斜め衝撃波を通過する流れには速度差が生じ，平板上の噴流軸付近のよどみ点圧力が その周囲よりも低くなる．このため，プレート衝撃波が上流側に突起のある形状を示したと考えられる．

よって, 第 1 セル内のプレート衝撃波の変動は, 不足膨張度が低い状態では, 反射衝撃波との干渉状態におい てプレート衝撃波の頂点部分のみ変動が大きくなる．したがって，プレート衝撃波自体の軸方向の振動は小さく， プレート衝撃波の形状が時間的に変化すると考えられる．不足膨張度の高い場合では，常に入射衝撃波と干渉状 態にあり, プレート衝撃波の底辺と頂点の変動が共に大きく, プレート衝撃波の形状と形成位置か時間的に変動し ていると考えられる.ここで, プレート衝撃波の形状や発生位置が変動するということは, プレート衝撃波-平板 間距離が変動しているということであり, 平板上のよどみ点圧も変動すると考えることができる .

\subsection{2 非軸対称の振動}

図 12 にプレート衝撃波の底辺およびセル節のノズル出口面に対する傾き角度の偏差を示す . 図中の破線は図 11 と同じくプレート衝撃波の形成領域の境界, 下端部はプレート衝撃波の形状を示している .この偏差はプレート 衝撃波やセル節の振り子状の变動の度合いであり，この值が大きくなると非軸対称性か強くなることを表してい る.プレート衝撃波の傾きの変動も位置の変動と同樣に不足膨張度の低い $p_{0} / p_{a}=3.0 や 3.4$ である图 $12(\mathrm{a})$ およ び (b) と不足膨張度の高い $p_{0} / p_{a}=3.8$ である図 12 (c) で異なる傾向を示した . プレート衝撃波が第 1 セル内に存 在する場合においては, 变動が増大するノズル平板間距離の範囲が図 11 と類似する結果を示した .

図 12(a)および(b)では, プレート衝撃波の偏差は, 第 1 セル中ではプレート衝撃波と反射衝撃波が干渉する $l / D$ の範囲 (青色) で大きい值を示す.これは 4.3.1 項でも述べたようにプレート衝撃波と反射衝撃波が干渉すると，プ レート衝撃波の強さは均一ではなくなり, 頂点部分の軸方向変動が大きくなる . この頂点部分の変動により下流が 乱れプレート衝撃波が非軸対称な挙動を示し，傾きの変動が大きくなると考えられる．また，第 2 セル移動後で は, プレート衝撃波が平形の場合は, 変動の值は $l / D$ か増加してもほぼ一定となる . さらに $l / D$ か増加し, プレー 卜衝撃波の形状が弓形となると非軸対称の変動は大きくなる傾向を示した .

図 $12(\mathrm{c})$ の $p_{0} / p_{a}=3.8$ では, 第 1 セル内では, プレート衝撃波と入射衝撃波との干渉が生じる $l / D$ の範囲 (橙色) で変動の值か増加する傾向を示した .これは, $4.3 \cdot 1$ 項で述べたように $p_{0} / p_{a}=3.8$ では，プレート衝撃波の頂点， 底辺ともに変動が大きくなり, プレート衝撃波自体が大きく振動している影響により, 兴の変動に付随する樣にプ レート衝撃波の傾きも増加したのではないかと考えられる . 第 2 セル移動後は，他の 2 条件の圧力比と同じくプ レート衝撃波の形状は平形となるため, 偏差の值は同樣に小さくなる傾向を示した . このことから, 第 2 セルに 移動後のプレート衝撃波の傾きの変動は, 不足膨張度の依存性は低くプレート衝撃波の形状が重要な因子である 
と考えることができる．

よって, 第 1 セル内にプレート衝撃波が存在する場合は, 軸方向の変動と非軸対称の変動が同樣の樣態で増加す ることから, 両者の変動は連動していると考えられる .このため, プレート衝撃波の位置や形状の変動が激しい と, 非軸対称の変動も激しくなる．また, 第 2 セル内にプレート衝撃波が存在する場合は, 軸方向と非軸対称の 変動の関連性は弱く, 非軸対称の変動のみプレート衝撃波の形状が弓形になると増加する . したがって, 第 2 セ ルでは非軸対称の変動のみがプレート衝撃波の形状に関連して変動の大きさが変化すると考えられる .

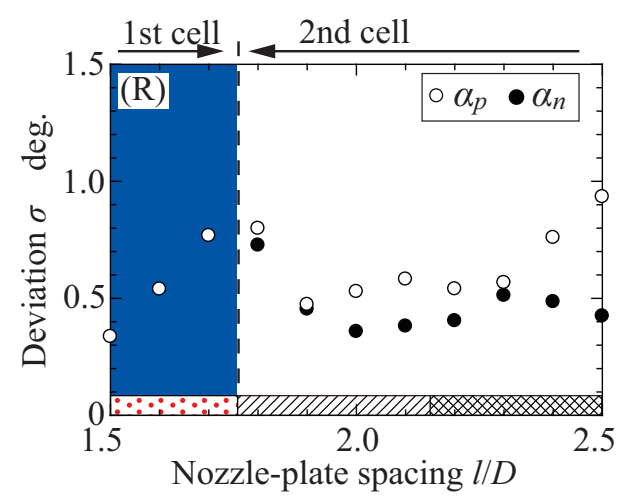

(a) $p_{0} / p_{a}=3.0$

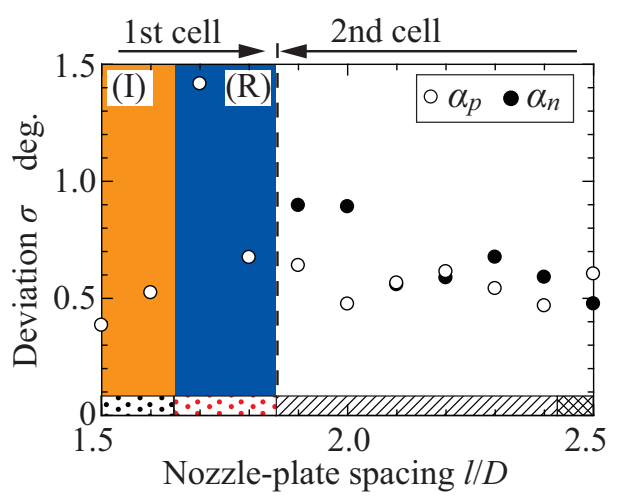

(b) $p_{0} / p_{a}=3.4$

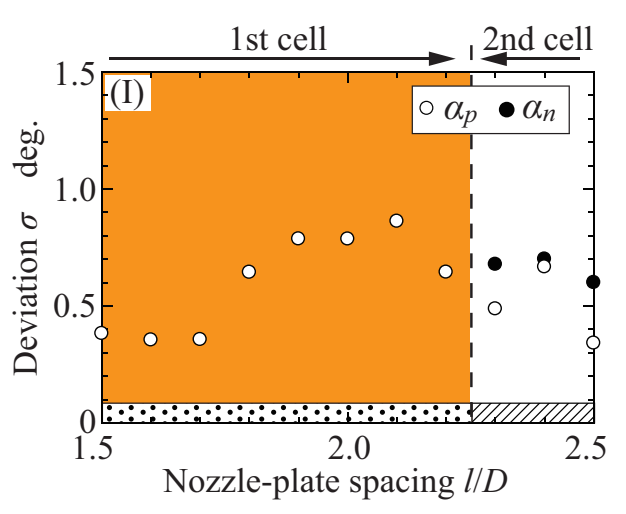

(c) $p_{0} / p_{a}=3.8$
Shape of plate shock

VIIA Flat type

Bow type

$\because \because$ Trapezoid type

$\because \because$ Trapezoid type (with curvature)

(I) Interaction of plate shock and incident shock

(R) Interaction of plate shock and reflected shock

Fig. 12 Deviations of angle of plate shock and cell node. Shape of plate shock is shown bottom of these figures.

\section{5. 結 論}

不足膨張衝突噴流の主噴流の挙動について, 光学的手法を用いて流れ場の可視化を行い, 不足膨張度の低い状 態とマッハディスクが形成されるような不足膨張度の高い状態のセル構造および衝撃波に着目し, 非定常な変動 について統計的な解析を行い以下の結論を得た .

- 第 1 セル内のプレート衝撃波の軸方向の変動は, 不足膨張度の低い場合は, 反射衝撃波との干渉状態におい て頂点部分のみ変動が大きくなり，プレート衝撃波の形状が時間的に変化する．不足膨張度の高い場合では， 常に入射衝撃波との干渉状態にあり, プレート衝撃波の底辺と頂点の変動が大きく，プレート衝撃波の形状 と形成位置が時間的に変動する.

・プレート衝撃波の非軸対称の変動は, 第 1 セル内では, 変動が増大するノズル平板間距離の範囲が軸方向の 変動と類似する . 第 2 セルでは, 形状が平形の状態の間は変動はほぼ一定となり, 平形から弓形の状態とな ると変動が増加する． 
・プレート衝撃波の軸方向および非軸対称の変動は，第 1 セル内では連動しており不足膨張度に強く依存する． 第 2 セル移動後は, 連動しない .

$$
\text { 文献 }
$$

Aratani, S. and Ojima, N., Effect of shock waves on fracture and quenching in tempered glass, Proceedings of the 18th International Symposium of Shock Waves (1991), pp. 1277-1282.

Barsom, J.M., Fracture of tempered glass, Journal of the American Ceramics Society, Vol. 51, No. 2 (1968), pp. 75-78.

遠藤正樹, 榊原洋子, 岩本順二郎, 放射状不足膨張噴流の時間平均的なセル形状に関する研究, 日本機械学會論文集

B 編, Vol. 72, No. 712 (2006), pp. 1901-1906.

Fieret, J., Terry, M.J. and Ward, B. A., Overview of flow dynamics in gas-assisted laser cutting, SPIE High Power Lasers, Vol. 801 (1987), pp. 243-250.

Iwamoto, J. and Deckker, B.E.L., Development of flow field when a symmetrical underexpanded sonic jet impinges on a flat plate, Journal of Fluid Mechanics, Vol. 113 (1981), pp. 299-313.

岩本順二郎, 井野川富夫, 平板に衝突する不足膨張噴流の流れパターンについて, 日本機械学會論文集 B 編, Vol. 55, No. 518 (1989), pp. 2983-2988.

Otobe, Y., Kashimura, H. and Setoguchi, T., Shock wave in supersonic moist air jet for a low pressure ratio, Journal of Thermal Science, Vol. 20, No. 4 (2011), pp. 289-293.

Panda, J., Shock oscillation in underexpanded screeching jets, Journal of Fluid Mechanics, Vol. 363 (1998), pp. 173-198.

Powell, A., Umeda, Y. and Ishii, R., Observation of the oscillation modes of choked circular jets, Journal of the Acoustical Society of America, Vol. 92, No. 5 (1992), pp. 2823-2839.

Powell, A., The sound-producing oscillations of round underexpanded jets impinging on normal plates, Journal of the Acoustical Society of America, Vol. 83, No. 2 (1988), pp. 515-533.

Raman, G., Screech tones from rectangular jets with spanwise oblique shock-cell structures, Journal of Fluid Mechanics, Vol. 330 (1997), pp 141-168.

榊原洋子, 岩本順二郎, 不足膨張衝突噴流に関する研究 (オイラ一方程式の数值解について), 日本機械学會論文集 B 編, Vol. 60, No. 572 (1994), pp.1139-1144.

榊原 洋子, 遠藤 正樹, 岩本 順二郎, 放射状不足膨張噴流の流れ場に関する研究, 日本機械学會論文集 B 編, Vol. 71, No. 712 (2005), pp. 2922-2927.

Sakakibara, Y., and Iwamoto, J., Oscillation of impinging jet with generation of acoustic waves, International Journal of Aeroacoustics, Vol. 1, No. 4 (2002), pp.385-402.

Tam, C.K.W., Broadband shock associated noise from supersonic jets measured by a ground observer, AIAA Journal, Vol. 30, No. 10 (1992), pp. 2395-2401.

玉井弘二, 荒谷眞一, 早川直也, 高山和喜, $2.0 \mathrm{~mm}$ 厚風冷強化ガラスに関する実験, 日本セラミックス協会学術論文 誌, Vol. 110 (2002), pp. 299-303.

田村聡, 岩本順二郎, 不足膨張噴流および衝突噴流から発生する騒音について, 日本機械学會論文集 B 編, Vol. 60 , No. 579 (1994), pp. 3873-3879.

Yee, Y.C., Upwind and symmetric Shock-Capturing Scheme, NASA TM 89464 (1987).

\section{References}

Aratani, S. and Ojima, N., Effect of shock waves on fracture and quenching in tempered glass, Proceedings of the 18th International Symposium of Shock Waves (1991), pp. 1277-1282.

Barsom, J.M., Fracture of tempered glass, Journal of the American Ceramics Society, Vol. 51, No. 2 (1968), pp. 75-78.

Endo, M., Sakakibara, Y. and Iwamoto, J., A study of time-averaged cellular shape of underexpanded radial jet, Transactions of the Japan Society of Mechanical Engineers, Series B, Vol. 72, No. 712 (2006), pp. 1901-1906 (in Japanese). 
Fieret, J., Terry, M.J. and Ward, B. A., Overview of flow dynamics in gas-assisted laser cutting, SPIE High Power Lasers, Vol. 801 (1987), pp. 243-250.

Iwamoto, J. and Deckker, B.E.L., Development of flow field when a symmetrical underexpanded sonic jet impinges on a flat plate, Journal of Fluid Mechanics, Vol. 113 (1981), pp. 299-313.

Iwamoto, J. and Inokawa, T., On the flow pattern when an underexpanded jet impinges on a flat plate, Transactions of the Japan Society of Mechanical Engineers, Series B, Vol. 55, No. 518 (1989), pp. 2983-2988 (in Japanese).

Otobe, Y., Kashimura, H. and Setoguchi, T., Shock wave in supersonic moist air jet for a low pressure ratio, Journal of Thermal Science, Vol. 20, No. 4 (2011), pp. 289-293.

Panda, J., Shock oscillation in underexpanded screeching jets, Journal of Fluid Mechanics, Vol. 363 (1998), pp. $173-198$.

Powell, A., Umeda, Y. and Ishii, R., Observation of the oscillation modes of choked circular jets, Journal of the Acoustical Society of America, Vol. 92, No. 5 (1992), pp. 2823-2839.

Powell, A., The sound-producing oscillations of round underexpanded jets impinging on normal plates, Journal of the Acoustical Society of America, Vol. 83, No. 2 (1988), pp. 515-533.

Raman, G., Screech tones from rectangular jets with spanwise oblique shock-cell structures, Journal of Fluid Mechanics, Vol. 330 (1997), pp 141-168.

Sakakibara, Y. and Iwamoto, J., Underexpanded impinging jet : Numerical solution of euler equations, Transactions of the Japan Society of Mechanical Engineers, Series B, Vol. 60, No. 572 (1994), pp.1139-1144 (in Japanese).

Sakakibara, Y., Endo, M. and Iwamoto, J., A study on flow field of Radial underexpanded jet, Transactions of the Japan Society of Mechanical Engineers, Series B, Vol. 71, No. 712 (2005), pp. 2922-2927 (in Japanese).

Sakakibara, Y., and Iwamoto, J., Oscillation of impinging jet with generation of acoustic waves, International Journal of Aeroacoustics, Vol. 1, No. 4 (2002), pp.385-402.

Tam, C.K.W., Broadband shock associated noise from supersonic jets measured by a ground observer, AIAA Journal, Vol. 30, No. 10 (1992), pp. 2395-2401.

Tamai, K., Aratani, S., Hayakawa, N. and Takayama, K., Experimental investigation for $2.0 \mathrm{~mm}$ tempered glass produced by air quenching method, Journal of the Ceramic Society of Japan, Vol. 110 (2002), pp. 299-303 (in Japanese).

Tamura, S. and Iwamoto, J., Study on the noise generated from underexpanded free and impinging jet, Transactions of the Japan Society of Mechanical Engineers, Series B,, Vol. 60, No. 579 (1994), pp. 3873-3879 (in Japanese).

Yee, Y.C., Upwind and symmetric Shock-Capturing Scheme, NASA TM 89464 (1987). 